\title{
A STYLISTIC ANALYSIS OF THE LANGUAGE OF POLITICAL CAMPAIGNS IN NIGERIA: EVIDENCE FROM THE 2007 GENERAL ELECTIONS.
}

\author{
V. E. Omozuwa \& E. U. C. Ezejideaku
}

\begin{abstract}
Politicians all over the world embellish their language in a unique way to give extra effect and force to their message in order to achieve their objective of winning more votes. This can be embodied in rhetoric or propaganda, involving repetition, promise, colloquialism, word coinages, pidginized and figurative expressions. The denotative and connotative meanings of the figurative expressions are analysed. It is argued that propaganda as an aspect of this register is characterized by exaggeration, rhetorical questions, and abusive utterances.
\end{abstract}

\subsection{Introduction}

Language use in political campaigns has certain characteristic features which differentiate it from other varieties of language use. Common as some of these features may be in everyday situation, they remain very unique with politicians and politics. The language of political campaign embodied in propaganda and rhetoric, is persuasive. Politicians adopt these linguistic devices to cajole the electorate to vote for them and their parties by presenting themselves as the only capable persons for the job.

This study is a synchronic stylistic analysis of the various political utterances used during the electioneering process in Nigeria based on 35 political campaign materials randomly collected from the print media (mainly from the southern part of the country) during the just concluded elections into the various offices in the 2007 general elections in the country. The different stylistic devices politicians used to achieve their aim are examined from the stylistic point of view. This is to say that different situations call for different language use. 


\subsection{The Language of Political Campaigns as a Variety of Language}

According to Longe (1995:26), there are two types of language varieties: dialect and diatype (register). He defines register as "The variety of language according to use" in situations such as the language of advertisement, the language of religious worship, the language of political campaign, etc.(35). An interesting feature of register is that it shows the speaker's attitude, mood and feeling with respect to the subject of discourse, and the other participants in it. This is manifested through style which, itself, is an important aspect of register.

The language of political campaign as a variety of language use is intended to pass the needed information to the electorate with a view to convincing or appealing to them. It is usually laden with emotion and has the effect of causing the electorate to have a change of mind on an issue. Szanto (1978:7) describes the language of politics as a "lexicon of conflict and drama, of ridicules, and reproach, pleading and persuasion, colour and bite permeated. A language designed to valour men, destroy some and change the mind of others."

Politics is one aspect of human activities that use by far the greatest amount of propaganda. The word is often associated with deceit because propagandists have seldom scruples to lie or to distort the truth in order to persuade and gather people behind them. In fact, propaganda can be honest or dishonest, while its purpose might be to elicit help or tarnish image. Propaganda is a fundamental instrument of the language of politics. It is used in moulding and changing opinion.

Another feature of the language of political campaign that make it distinct and different from other forms of language use is rhetoric, which involves promises, biblical reference to God, repetition, figurative expressions etc., all at the same time. The politicians use rhetorical devises to embellish his words in order to cajole the electorate. This can sometimes determine the number of votes he eventually gets at the poll. In fact the success of a politician depends, to a large extent, on his rhetorical style in a truly democratic situation. A politician must be thoroughly equipped rhetorically in order to tie up an opponent and at the same time 
imbued with the power of arousing emotions of anger or pity in the electorate. The language of political campaign, whether it is in the interrogative, declarative, imperative or exclamatory mode, contains some forms of promises to the electorate.

\subsection{Propaganda}

Szanto (1978: 6) sees propaganda as "a specific form of activated ideology." He argues that propaganda is one of the manifestations of the ideology that involves the selling of specific concepts. According to Longe and Ofuani, (1996:17) “... The sole purpose of propaganda is to misinform and mislead and to consciously indoctrinate." Propaganda aims at deliberate slanting of facts and arguments as well as displays of symbols in ways the propagandist thinks will have the most effects. For maximum effects, the propagandist may deliberately withhold pertinent facts, and try to divert the attention of the people he is trying to sway from every but his own propaganda. This is why Szanto (1978:5) argues that propaganda could be "total falsehood, on the one hand, and on the other a totally valid depiction of reality or truth." Politicians attempt to persuade their audience by means of expressions that may damage the character of the opponent and discredit him through a conscious manipulation of language. Longe and Ofuani (1996:17) therefore, argue that propaganda is derogatory because it tends to "damage or take away credit" from something or someone. Propaganda could be in form of exaggeration, rhetorical questions, vague and abusive utterances, etc. The electioneering campaign of the April 2007 general elections in Nigeria is characterized by a massive use of propaganda. Consider the following:

\section{1 Propaganda Through Exaggeration}

Exaggeration is one of the peculiar features of political propaganda. It could be through the exaggeration of one's little achievements or the over-bloating of the wrong acts of the opposition. Politicians present the wrong doings of their opponents in such a way that even their opposition's supporters would want to reconsider their stand. Consider the extract below:

They told us they have reformed the economy. Which economy? 
- No Electricity! 95\% of Business And Homes Depend on Generator for electric power

- No fuel! Government imports $100 \%$ of petroleum products for local consumption

- Insensitivity! Our roads are death Traps, infrastructure are Derelict

- Insecurity! Security of lives And property Almost Non existent

- Poverty! There is Absolute Hunger and Unemployment in the land.

...And now they tell us election will be a do or die affair?

Nigerians will be alive to enjoy the real benefit of democracy.

OUK 2007. Vote ORJI UZOR KALU.

(Daily Sun, Tuesday, April 17, 2007: 5).

The above extract is a typical example of propaganda through exaggeration. The information contained in the sponsored advertisement was exaggerated. Though it is a fact that the supply of electricity in Nigeria is erratic, it is an exaggeration to say that $95 \%$ of business and homes now depend on generator. Similarly, Dr. Andy Uba exaggerates his meeting the President, Gen. Olusegun Obasanjo, to be a divine arrangement: He says "My meeting the president was made in heaven" (Daily Champion, Friday, Mar 30, 2007: 6). This is impossible because he has not been to heaven.

The phrases, 'the magnificent' and "the product of the sweat of the founding fathers of Lagos" were tactically used to exaggerate the fire outbreak of April 30, 1998 in the Lagos City Hall when Senator Obanikoro was the Chairman of the Lagos Island City Council (The Nation, Saturday, March 17, 2007). Those that have not seen the City Hall before would think it is one of the most beautiful edifices in Lagos

\section{2 Propaganda Through Rhetorical Questions}

Richard, Platt, and Platt (1992:136) defines rhetorical question as "a forceful question which has the form of a question but which does not expect an answer." Going by this definition, 
rhetorical questions are questions for which the speakers already have the answers (or they are self evident) but sarcastically ask them to discredit the opponent. Consider the two rhetorical questions in the extracts below:

"...what would have happened if Koro had been chairman for 3 years?"

The propagandists provided the answer:

"The whole of Broad Street would have been razed to ashes."

This was closely followed by the second rhetorical question: "Is this the man who should ever have the effrontery to desire to become the governor of Lagos state in this era of accountability and transparency?" They warn: "Alausa", the seat of Lagos State Government, "must not catch fire!" And advise that "Lagosians must arise and elect a credible Governor." (The Nation, Saturday, March 17, 2007:4).

Other examples of rhetorical questions are:

“... But can 2 weeks of 'patch' patch' activities salvage 8 wasted years?" (Saturday Punch, March 10, 2007:A 18);

"They told us they have reformed the economy, which economy?" (Daily Sun, Tuesday April 17, 2007: 5).

These questions do not need any answer; the answers are already evident with the facts provided by the propagandists. This stylistic device is very effective as the propagandists use such rhetorical questions to provoke thoughts on the part of the audience; to make the audience see why they must reject their opponents.

\section{3 Vague Utterances}

Politicians make use of certain words that are vague or indefinite, i.e., words that have no realistic ways of validating them. Like rumour, they lack verifiable facts. Example of such vague utterances can be seen in the extract below:

1. Lagos reject bitterness (Thisday, Saturday, March 17 2007: 27)

2. Go Ahead! We love you. Lagosians (Punch, Tuesday, March 20, 2007 p: 47)

3. Kalu doesn't respect old age, tradition. (Obasanjo. Punch, Saturday, March 3, 2007). 
All the extracts above are not definite, they lack clarity. Here, one person is speaking for everybody. The opinion expressed may not necessarily be everybody's.

\subsection{Abusive Utterances}

Politicians, in their desperation to discredit their opponent, use some utterances that may be termed abusive. These utterances may be consciously or unconsciously used. Examples of such abusive utterances are seen in the extracts below:

"Later I made Segun Mimiko Minister without the knowledge of Agagu. What I am hearing now is that he said I am the one that urged him to go and contest in another party. He is a lair. I did not say any such thing. When he told me that he wanted to resign as Minister to go and contest, I begged him not to go, I don't know whether his mother's rival cursed him,.."

(Sunday Independent. February 11, 2007: 33. South - west Zonal PDP President Campaign Rally at Akure Sports Stadium. Emphasis is ours).

2. "Atiku turned out to be such a person that when he says good morning to you, you have to open the window first to check what time of day it is before you answer him. I apologize for making the wrong decision." (Vanguard Feb 26, 2007: 43)

The extracts above show the recklessness in the use of language. Politicians become too emotional in spreading propaganda that they resort to abusive language. The words by President Olusegun Obasanjo about the person of the Vice President, Atiku Abubakar, are not also palatable. The President used a more vulgar expression to address the Labour Candidate in Ondo State, Chief Mimoko. He referred to him as "a liar" and somebody that has probably been "cursed by the mother's rival." Other expressions like "they are empty", "a toy Governor" (Sunday Punch, March 18, 2007, :41), "without proper upbringing" (Punch, Tuesday March 20, 2007, P:47), are all abusive language. They are meant to defame the character of the opponent.

\subsection{Attack on Party Logo and Slogans}

Other ways politicians spread propaganda is through the use of negative expressions to refer to their opponents' party slogans or 
logo. This is aimed at drawing the attention of the audience to the negative things they may expect if their opponent's party is voted into power. Consider the following:

1. “...Next Step. To become the popularly elected Governor of Lagos state in 2007, by the grace of God and the will of the people. Because he whom God favours, no amount of witches and wizards with broomsticks can prevent against! Musiliu Obanikoro For Lagos state Governor 2007. (Punch, Friday March 16, 2007: 36).

Senator Afikuyomi made the above statement in response to Tinubu's at a rally in which the latter referred to him (Afikiyomi) as "chicken holding corn to chop" (Sunday Vanguard. March 11, 2007:10), and tagged Tinubu's anointed candidate at the time (Fashola), as "a toy Governor" (Sunday Punch, March 18, 2007: 41).

Politicians try to present their opponents' political parties in bad light. The Peoples Democratic Party was likened to "Papa Deceiving Pickin" (Thisday, March 15, 2007:12) and "Power of Darkness Permanently" (Thisday, March 17, 2007). The propagandists attack the logos of the Action Congress and the All Nigerian Peoples Party (ANPP). The Action Congress' logo (a broom) is referred to as an instrument of witches and wizards while that of the All Nigerian Peoples Party (a cob of corn) is referred to as food for chickens. These messages, though comical, are meant to present the parties and their members in bad light.

\subsection{Rhetoric}

Richard, Platt and Platt (1992) define rhetoric as "the study of style through grammatical and logical analysis." It is therefore "the art or talent by which discourse is adapted to its ends" Rhetoric differs from propaganda in the sense that while the former aims at persuading through the beauty of language, the latter seems to persuade through some negative manipulation of language.

Rhetoric is the study and practice of effective communication; the art of persuasion, and an insincere eloquence intended to win points and get people what they want. Politicians endear themselves 
to the audience's heart through different rhetorical skills such as repetition, bible citation, rhetorical questions, colloquialism, promise, use of pidgin, word coinage etc.

\subsection{Repetition}

This is deliberately saying the same thing over and over again for emphasis. Repetition of a particular word, phrase or an idea helps the listener to memorize the word, phrase or idea. Politicians repeat the same words several times so that the ideas or concepts will be better comprehended by their audience. Examples of such repetitions in the 2007 electoral campaign are shown in the extracts below:

1. Free Education. Free Medical care. Free Medical care. Free Employment. Free food. Free house. Free this ... Free that (Concerned Citizens for a better Lagos: Saturday Punch, March 31, 2007: A19).

2. Empty seat, Empty excuses, Empty promise, Empty politics. They are empty (Sunday Punch March 18, 2007: 41; emphasis is ours)

In the first extract, the word 'free' was repeatedly used to comically discredit the opponent. By repeatedly saying 'free' the politicians tried to show that 'free' has become a slogan to their opponents since nothing was actually free. Similarly, in the second extract, the politicians repeatedly used the word 'empty' to show the emptiness in their opponents. By repeatedly saying 'empty' the listeners are compelled to believe that the opponents have nothing to offer. The above extracts reveal that repetition, in the rhetorical use of the language of political campaign, is a very useful tool for emphasis to portray the opponent in bad light.

\section{2. Biblical Citations/Reference to God}

Politicians, especially in Nigeria, have recourse to citing references from the HolyBible to compel the electorate to vote for them and their political parties. The reason is to give spiritual credence and authority to their speech they believe that majority of Nigerians are very religious. An example of biblical citation can be seen in the reply given by Chief Ojo Maduekwe (the then Peoples Democratic Party National Secretary) when he was asked to comment on the decamping of the founding members of his party. 
He drew analogies from the Holy Scriptures as seen in the following extract: 'If you want me to be modest, I will tell you that we have left Egypt, but we have not yet reached Canaan. We are still between Egypt and Canaan. We are in the wilderness. That wilderness is a much better place to be than Egypt, especially when you have a Moses with you and that Moses, of course, is President Olusegun Obasanjo. We have a Joshua in the wing. That Joshua seems to be Yar' Adua.' (Daily Champion, Monday 12, 2007).

Similarly, the Action Congress Politicians made reference to the Book of Samuel(17 : 45) where David was quoted as saying "...thou comest to me with a sword, and with a spear, and with a shield: but I come to thee in the name of the LORD of hosts, ..." (King James Version). Chief Adams Oshiomhole, Action Congress gubernatorial candidate in Edo State, was likened to David. They believed he would be the little David that would destroy the giant called the People's Democratic Party whom they believed would use the Police and the Army against the opponents.

\section{3 Promises}

Politicians make use of expressions that are full of assurance and hope for a better tomorrow to sway the opinion of the electorate. Virtually all the political campaign materials are laden with promises. This is one unique way politicians hold their audience spell bound. An example is presented below:

"Our vision is to banish poverty in Ekiti." (Action Congress gubernatorial candidate in Ekiti State, Kayode Fayemi. Saturday Champion, March 30, 2007 : 11).

Politicians make various promises both realistic and unrealistic. These, they use to persuade their audience to vote for them at the polls. Promises constitute a great deal of rhetorical devices in the language of political campaigns. Kalu, promised amongst other things to reform the Police by making sure that State Police will not be like “Obasanjo's Police” (Sunday Vanguard, March 11, 2007:7; consider also Sunday Champion, May 18, 2007 and New Age, Thursday, March 15, 2007:13). 


\section{4 Colloquialisms}

The purpose of this type of language used by politicians is to show solidarity with the audience, especially the masses. Examples of this style of rhetorical device are shown below:

1. "But can 2 weeks of 'Patch patch' salvage 8 wasted years?" (A sponsored campaign by the Musili Obanikoro Campaign Organization. Saturday Punch, March 10, 2007: A18).

2. FA! FA!! FA!!! FASHY THEM. (Concord Citizens for a better Lagos. Saturday Punch, March 3, 2007: A19)

Politicians use such colloquial terms as "no shaking", "patch-patch", "fa!fa!! fa!!! Fashy them", "catch fire", etc., as a mark of solidarity with the grassroots. These expressions are already familiar to the audience that is being addressed. Item 2 in particular falls into the category of coinage while remaining a colloquial expression. After "fa!fa!! fa!!!, one would have expected the usual "foul" but "Fashy them" was coined from the name "Fashola", the Lagos State Action Congress gubernatorial candidate at the time, by the opponents to mean "ignore them," in this case.

\section{5 Word Coinages}

Word coinage is the process of inventing new words to suit the present discourse. This feature is different from colloquialism because while colloquialism involves words/expressions that already exist but not acceptable in formal discourse, coinages are words/expressions that do not exist but are coined to suit the present discourse. One of the examples of word coinage as used by Nigerian politicians is presented in the extract below:

"...This is why we must reject the PDP man "Koro" (bitterness) in Lagos....PDP must not be allowed to "KORODE" Lagos..." (Concerned Lagosians for Good Government. Sunday Sun Newspaper, Thursday, March 25, 2007: 24)

From the extract above, the coinage of the word "Korode" from the Yoruba word "koro" (bitterness) was a veiled reference to the Lagos State PDP gubernatorial Candidate, Senator Obanikoro, by his opponents. This is homophonic with the verb "corrode". The message seems to suggest that electing him will "corrode" Lagosians and bring bitterness to them. Another example is seen in the following extract: “... why Muhammadu Buhari will not win. Say 
no to brutality now. Say no to Bruharity too" (Daily Sun, Tuesday, April 17, 2007:20). "Bruharity" is adapted from the English word 'brutality' in reference to Gen. Muhammadu Buhari's alleged brutality during his tenure as Nigeria's military Head of State. These coinages are not only to pass the message clearer to the audience but also to add humour to the discourse.

\section{6 Pidginized Expressions}

Another strategy politicians adopt to capture the attention of the man on the street is through the use of pidgin. Pidgin, like colloquialism, is used to create a seeming affinity with the people at the grassroots. Politicians have recourse to pidgin especially when they want to address the people in rural areas or the masses. Consider the following extracts from Reverend Chris Okotie's speech (Fresh Party presidential candidate) during his campaign rally in Ajegunle:

1. "wen una vote for me and I get to Aso Rock in May this year, I promise una here now that I go build hospitals, schools, which go be free for every citizen because Nigeria get the money." (Sunday Vanguard, March 2007 : 7)

2. "You know say my papa no be rich man, my papa no get money, and I no how him struggle take send me go school, and now when I don go school and you know say I sabi oyibo well well. When I become president everybody for Ajegunle go fit go school. Una no say una be my own people" (Sunday Punch March 11, 2007: 14)

The Reverend-turned-Politician tried to show his solidarity with the people in Ajegunle (one of the most populated ghettos in Lagos) by using the language they understand better, 'pidgin'. Politicians know that the masses constitute more than $60 \%$ of the electorate there. Therefore, they use the language they understand to solicit for their support. This makes the people feel the politicians have them in their agenda.

Former president Obasanjo is another known politician who resorts to the use of pidgin when he wants to address the masses and people in the rural areas. One of his statements, a reply to questions on the health condition of his party's presidential candidate, Musa Yar' Adua, during their South East rally in Abia State is presented below: 
"He is strong. If you push am you go fall" (Thisday, Monday, March 19, 2007: 20. emphasis is ours).

\subsection{Figurative Expressions}

Figurative expressions are words or expressions that differ from the customary everyday conversational use of such expressions for the purpose of assigning them a special meaning. We should thereby understand them with their connotative meanings rather than their denotative meanings. Awonusi (in Essien and Okon 2003:97) argues that "figures of speech are used as rhetorical devices especially when politicians are confronted with abstract concepts which are difficult to explain for the easy understanding of the layman." What this means is that there are some figurative expressions that politicians use so that their speech will be better appreciated. The figures of speech that will be discussed in this section are metaphor and idiom.

\subsubsection{Metaphor}

This figure of speech expresses an idea through the image of another object. Metaphors suggest the essence of the first object by identifying it with certain qualities of the second object. According to Awonusi (in Essien and Okon 2003:98) "The common source of metaphor in politics are sport and war, both of which involve some form of physical contest". An example of metaphor used in the language of political campaign is presented below:

"Smart Guy. He couldn't take the heat. So, he stayed out of the kitchen" (Sunday Sun, March 16, 2007: 12)

In the extract above, the politicians compared what Senator Obanikoro (the PDP gubernatorial aspirants in Lagos state) would have faced if he had attended the public debate to the heat that came from the kitchen. In another instance, Atiku Abubakar's arrival is compared with the landing of the eagle, the king of birds (Saturday Punch, March 24, 2007). It presents Atiku Abubakar as having great political strength similar to the strength of the eagle. Similarly, Ziggy Azike, ANPP gubernatorial candidate in Imo State describes himself as a good footballer and explains how he is capable of great political skills (Sunday Sun, March 13, 2007:12). The use of the concept from the sport jargon could be to get quick attention from 
the audience, since football is one of the things that unite the country.

\section{7 Idioms}

Idioms are phrasal constructions or verbal expressions closely associated with a given language. Africans, especially Nigerians, enjoy the use of idioms in every day speech. Consider the following examples:

1. "The problems of Niger Delta go beyond the issue of derivation fund, the issue is that the people made the mistake of putting their eggs in one basket. They have been in the same party for eight years." (Sokoto State governor and presidential candidate of the Democratic Peoples Party DPP, Altahiru Bafarawa, urging the people of Niger Delta to reject the PDP in the General Elections. Weekly Spectator, March 18, 2003: 24)

2. He who pays the Piper dictates the tunes. Ekiti, beware! The devourers are here again. (Friday Punch, April 16, 2007: 18)

The italicized parts of the extracts above are good examples of idioms used by politicians during political campaign as a way of giving extra meaning to an utterance.

\subsection{Conclusion}

This study reveals that Nigerian politicians, like their counterparts in other parts of the world, use language in a unique way during political campaigns to give extra effect and force to their message. This is aimed at achieving their main objectives of discrediting their opponents and winning more votes. This style of language is embodied in either rhetoric, or propaganda. Repetition, promises, colloquialisms, word coinages, pidginized and figurative expressions are some of the features of this register. This paper reveals that politicians will spare nothing at outsmarting their opponents even if it means resorting to the use of utterances that could be defamatory, abusive and sometimes vulgar. For them, therefore, in the political arena, as it is in war, "all is fair." It is however the opinion of the present writers that since a lot of responsibility is placed on the shoulders of the political elites, they should be mindful of what they say, where, how, and to whom they say it. This study is by no means exhaustive. It is expected that 
further studies based on a diachronic data on the language of political campaign in the Nigerian context and elsewhere be carried out so that Nigerians will better appreciate the importance of the use of a 'refined language' in politicking. 


\section{References}

Abraham, M. H (1995): A Glossary of Literary Terms. London: Holt, Rhine Hart and Winston.

Essien Okon and Margaret Okon (2003): Topical Issues in Sociolinguistics: The Nigeria Perspective. Aba: National Institute of Nigerian Languages.

The Holy Bible, Kings James Version. London: Tyndale House, 1967 Edition.

Hudson, R. A. (1980) Sociolinguistics. Cambridge. Cambridge. Cambridge University Press.

Longe, V. U (1995): Studies in the Variety of Language. Benin City: Headmark Publishers.

Longe, V. U and Ofuani, O. A. (1996): English Language and commutation. Benin City: Educational Research Association

Richard, C. Platt, J. and Plait. H. (1992). The Longman Dictionary of Language Teaching \& Applied Linguistics. New Edition. London: Longman.

Szanto G. H (1978). Theatre and Propaganda. Austin: University of Texas Press.

\section{Newspapers}

The Champion: Friday, March 30, 2007; Sunday Champion, May 18, 2007.

The Daily Independent: Sunday, February 11, 2007.

The Nation: Saturday, March 17, 2007.New Age: Thursday, March 15, 2007.

Punch: Saturday, March 3, 2007; Saturday, March 10, 2007; Sunday, March 11, 2007; Friday, March 16, 2007; Sunday, March 18, 2007; Tuesday March 20, 2007; Saturday, March 24, 2007; Sunday, April 7, 2007; Friday, April 16, 2007.

The Sun: Sunday, March 11, 2007; Thursday, March 25, 2005; Tuesday, April 17, 2007.

Thisday: Thursday, March 15, 2007; Saturday, March 17, 2007; Monday, March 19, 2007; Saturday, March 30, 2007;

Vanguard: Monday, February 26, 2007; Sunday, March 11, 2007; 